repeated exercises, where

“making is thinking”; (24-35,

How to Think Like Shakespeare: 85-95)

Lessons from a Renaissance

Education, Scott Newstok, Princeton

University Press, 2020, 185 pp. + xv,

$\$ 16.14$ hardcover.

\section{How to Become Educated}

\section{David Randall}

Scott Newstok, professor of English and founding director of the Pearce Shakespeare Endowment at Rhodes College in Memphis, argues for the value of a Renaissance education in How to Think Like Shakespeare. He does so by means of a lucid, attractive essay that wears its learning lightly and with style.

What should students learn? Newstok gently advocates that they acquire "Shakespearean habits of mind ... thinking-not training a set of specific skills." (ix) He describes the loosely interwoven components of this Shakespearean education:

- demanding, disciplined craft, a practice and art honed by decorum, fitting action and writing to an occasion, a practice that develops into the artfully artless graces of personal teaching and personal style; (37-45)

- the linked importance for education of physical places (colleges) and mental "places"-topics of study and vivid images on which to ground further thought; (46-53)

- $\quad$ sustained attention rather than high-tech distraction; (55-61)

- imitation of excellent models, to think through how artists created great works so as to learn how to create one's own work; (73-83)

- conversation that teaches students how to engage in civil discourse, to learn how to “occupy (at least) two sides of the question (or dilemma, or paradox) with equal vigor and rigor, inducing a nimble, anti-doctrinal equipoise"; (96105, esp. 101)

- tradition, relabeled stock, the long conversation of the

David Randall is director of research at the National Association of Scholars, 420 Madison Ave., $7^{\text {th }}$ Floor New York, NY 10017; randall@nas.org. His most recent books are The Concept of Conversation: From Cicero's Sermo to the Grand Siècle's Conversation (2018) and The Conversational Enlightenment: The Reconception of Rhetoric in Eighteenth-Century Thought (2019). 
ancients which we have the privilege to join and, if educated properly, the capacity to continue; (108-17)

- the value of constraint within given forms to generate artistic beauty precisely by submitting to any genre's rules of the game, which form its particular long conversation and tradition; (119-29) and

- the ultimate dedication of education to bildung, eminently Renaissance self-fashioning, the making of self which acknowledges that we must submit to soulcraft, educate ourselves, if we are to become our best selves-and thereby, in the only sense of the word that truly matters, free. (131-51)

In sum, Newstok argues for education formed by the principles of Renaissance rhetoric: "Rhetoric wasn't just part of the curriculum; it was the curriculum. Because thinking and speaking well form the basis of existence in a community, rhetoric prepares you for any occasion that requires words-it's the craft of future discourse.” (23) Put another way: “An education in the Shakespearean language arts has a Boy Scout quality: $B e$ Prepared. Its advantage lies in the fact that it works, stretches, and enlarges the tool most characteristic of the human: the mind." (105) Newstok acknowledges that America is no land of English gentleman, trained by lengthy construal of Latin grammar. He still believes that Shakespearean education suits a Whitmanesque, multitudinous democracy. "I'm not proposing that we reinstate corporal punishment, tedious rote memorization, or schools that exclude anyone. Thinking is the common property of all." (xi)

Newstok recapitulates his argument in his book's form: “Throughout this book, I've stitched together an almost endless collection of scattered thoughts and observations into a kind of patchwork, or cento, of passages that have inspired me." (xiii) He makes his essai a bricolage of quotationsextending backward to Heraclitus and Cicero and forward to $\mathrm{Du}$ Bois and King, but heavily Shakespearean, as when he illustrates how the Bard portrays characters caught thinking by referring to "the quick forge and working-house of thought." (Newstok 3; Henry V 5.0.23)

Newstok's mode of writing, which demonstrates to students how they should think, suggests the book should really have been titled How to Think Like Montaigne. Presumably the editors knew that Shakespeare still has a brand with the public, as Montaigne (hélas) does not. 
Newstok's bête noire is the standardized, too-thoroughly administrated college-the college of the soul-grinding quantifications of standardized assessment, of Gradgrindian utilitarianism, of instruction that conveys facts rather than modeling thought, of "depersonalized learning, via algorithmic surveillance at remote screens," (43, 47-48), of technology generally when proffered as a substitute for education. Newstok's essay here is a cri de coeur.

It is, however, a liberal's cri de coeur. Though Newstok spends little time on politics, his turns of phrase signal his ready acceptance of liberal conceits. He refers to "[s]avage inequalities in access to schools," and he adheres to what is now a standard critique of the "neoliberal" university. (27) These aspects of the book will not endear him to readers for which such pieties are not self-evident, but rather “irritable mental gestures which seek to resemble ideas" (Trilling).

Then too, for all his endorsement of thinking one's way into unfamiliar points of view, he does not take the time to explore the frame of mind of the assessors and the administrators he dislikes so much, to make the best case for the educratic regime. He might have done so, to provide an example to his readers of heroic empathy. Doubtless homo administrativus is in most respects a veritable Vogon out of The Hitchhiker's Guide to the Galaxy, "bad tempered, bureaucratic, officious and callous.” (Adams) But “A Man's a Man for a' that." (Burns)

Newstok's tacit critique of the illiberal left, now revolutionary, matters more than these minor shortcomings. He champions the Western tradition.

Nobel laureate Joseph Brodsky once taught a poem by Osip Mandelstam, Brodsky's hero who died in Stalin's gulag. Mandelstam alluded to Ovid. When Brodsky asked how many of his American students knew Ovid, no one answered. His stunned response: You've been cheated. (107)

Newstok also repudiates the idea that cultural appropriation is somehow wrong. He quotes Terence and Seneca: "I am human: nothing human is alien to me ... The best ideas are common property ... whatever is well said by anyone is mine." (145) Newstok also quotes James Baldwin's slow realization that he was free to overleap the color line he had thought did and should bar him from Shakespeare and his words: "If the language was not my own, it might be the fault of the language; but it might also be my fault. 
Perhaps the language was not my own because I had never attempted to use it, had only learned to imitate it." (147) Or, as a contemporary of Baldwin put it, "if we are in a jug it is transparent, not opaque, and one is allowed not only to see outside but to read what is going on out there" (Ellison; Ralph, not Keith).

Newstok quietly tells college students to avoid the road that leads to the iconoclastic fury of the academic left, now unleashed on America. He preaches the value and importance of place, but leaves for later discovery the realization that utopia is no-place. ${ }^{1}$ How to Think Like Shakespeare uses tact to preach the good news.

Such lessons are more vital than ever as America plummets into the Cultural Revolution's maelstrom. As the cheerleaders of revolutionary fury eagerly instill ignorance in their students and call it "activist and engaged education," the most practical way to pass on the bare willingness to look at the remnants of Western Civilization with an open mind is to introduce students to books such as Newstok's.

How to Think Like Shakespeare would have been a good book at any time; now it is a necessary one.

1 The word is not / In Liddell-Scott; / It came instead / From Tom More's head. 